\title{
Usability of Jawara Sains Mobile Learning Application Using System Usability Scale (SUS)
}

\author{
Ririn Suharsih $^{1}$, Rinanda Febriani ${ }^{2}$, Sutadi Triputra ${ }^{3}$ \\ ${ }^{1,2,3}$ Department of Informatics, Universitas Muhammadiyah Bandung, Indonesia
}

\begin{tabular}{l} 
Article Info \\
\hline Article history: \\
Received Feb 8, 2021 \\
Revised Apr 25, 2021 \\
Accepted May 2, 2021 \\
Published June 30, 2021 \\
\hline Keywords: \\
Interactive Multimedia \\
Learning \\
Mobile Learning \\
System Usability Scale \\
Usability \\
\hline
\end{tabular}

\begin{abstract}
The application of interactive learning multimedia is one of the factors that impact the learning process for achieving learning outcomes. In developing a mobile application, the main principle is usability. This research goal is to presents a usability evaluation of the Jawara Sains, which is a mobile application to learn science subjects. This research used a System Usability Scale (SUS) questionnaire to measure the level of users' perceived usability. This score can indicate the usability performance of effectiveness, efficiency, and ease of use. Jawara Sains's SUS score achieved 75.45, which indicates a $\mathrm{B}$ grade, acceptable, and categorized in the good range. This score can also indicate whether a user is a promoter or not. The analysis showed that the Jawara Sains is categorized into the passive Net Promoter Score (NPS), which means users will not influence other people. Therefore, recommendations are needed for its usability improvements.
\end{abstract}

\section{Corresponding Author:}

Ririn Suharsih,

Department of Informatics,

Universitas Muhammadiyah Bandung,

Jl. Soekarno Hatta No. 752 Bandung, Indonesia

Email: ririnsuharsih@gmail.com

\section{INTRODUCTION}

Learning in the era of disruption must provide sustainable learning skills so that students can go through the era of disruption and enter a new era called the Abundance Era. The development of technology impact learning activities as they have shifted the education from teacher-centered to learner-centered. Many online learning sites are found, Khan Academy, Bju's, Mathway, Ruangguru, Zenius, Quipper, etc. The extensive use of smartphones by students is a great potential to build a mobile-based interactive learning media application as a medium for independent learning, especially during distance learning. The challenge in this industrial revolution era is to change the strategies models learning under the demands of the times and technology. Most mobile applications used in science teaching and learning were developed by researchers. The previous study proposed the development of an android application for calculating variable science electric magnet [1] and a mobile application using APPYPIE for learning science[2], both of this research was limited based on expert validation rating and has not measured of a user's perception of its usability. The results of usability testing can be the first step in evaluating the application. Also, it was essential to demonstrate that there were measurable improvements between one version and another[3]. Usability is usually closely related to this utilization of the system for users to help them.

Jawara Sains application is a mobile learning application in science subjects for High School students or equivalent. This application features material, video, animation, quizzes, and virtual experiments. Users download it so that they can keep learning even the device is not connected to the internet. The purpose of designing this mobile application is to develop a mobile learning application that allows students to carry out other activities such as simulations and virtual experiments, not only reading material, watching videos, or just doing exercise. This is in line with Surjono's opinion [4] that multimedia learning must be interactive to provide opportunities for students to do activities, for example, page navigation, menu control, buttons, links, animation, drag and drop, simulation controls, etc. There are many benefits of using interactive learning media. 
According to research conducted by Siswanto show that using a scientific approach-integrated virtual simulation has enormous potential in training student's science process skills [5]. As stated by Vebrianto that using various learning media can help student increasing their knowledge and developing their skills in science [6]. Also, effective learning occurs when the learner interacts with multimedia content and activity feedback to improve their skills [7]. Jawara Sains is expected to fit it all and add variety to conventional learning fully.

The development process used to develop Jawara Sains is the ADPED model, which consists of Analysis, Design, Production, Evaluation, and Dissemination. Jawara Sains is a mobile application that provides interactive learning multimedia content. The ADPED development model is proposed because this model is one of the interactive multimedia development models inspired by the research needs of the research and development type [4]. The evaluation stage in this model also requires expert validation to determine the feasibility of the application. They were so based on these reasons, the researcher using this model to develop this mobile learning. At the evaluation stage, one of the factors that must be fulfilled is usability. There are three main measures of usability based on The International Standard Organization (ISO) definition [8]. Effectiveness refers to the behaves of a product in a way that users expect and use to do what they want with ease. Efficiency is the speed at which the user's goal can be achieved accurately and is usually measured in units of time. Satisfaction refers to the user's perceptions, feelings, and opinions about the product [9].

There are numerous surveys available in assessing the usability of a product or service, e.g. SUS (System Usability Scale), SUMI (Software Usability Measurement Inventory), QUIS (Questionnaire of User Interface Satisfaction), and PSSUQ (Post Study Usability Questionnaire). The SUS consisted of ten questions, easy to implement, ranging from 0 to 100 , and freely available $[3,10]$. SUMI is a fifty-item questionnaire, very reliable but requires purchasing a license [11]. The QUIS consists of twenty-one questions, measure specific interface factors, and it is not accesible [12]. PSSUQ is a questionnaire with sixteen questions, provides a total satisfaction score with the average subscale of system, information, and interface quality, and it is available free of charge[13].

Of the several types of usability assessment questionnaires above, this research used SUS to measure the usability of the Jawara Sains App because SUS shows several advantages. It only consists of ten questions, so it is relatively quick and easy for participants to complete. The measure was administered quickly and simply, unburdened, valid, and reliable even with a small sample size [14, 15]. Also, reliable to be used to make comparisons of user performance change between one version and another of a software application. Usability problems can cause users to get confused when using the app, making them reluctant to return to using the app. The interpretation results based on the SUS score obtained, can be correlated with the Net Promoter Score (NPS), which relates to the possibility of a user recommending the Jawara Sains apps. The results of data analysis from the SUS score can help the researchers understand how real users interact with this mobile learning and make changes based on the next application development steps. Therefore, the primary goal of this research is to explore the usability evaluation of Jawara Sains through the SUS instrument.

\section{METHOD}

ADPED model is used in the development of this application. It consists of analysis, design, production, evaluation, and dissemination [4].

\subsection{Analysis and preliminary research}

Needs analysis is carried out to obtain information about the problems faced by the teacher, proposed solutions, and software requirements that are under the needs in the field. The data were obtained through the questionnaire results on the needs of the interactive learning multimedia application for Science-Physics subjects. The sample consisted of 49 respondents was taken from the population of high school physics teachers. Several items in this questionnaire were adapted and modified from the research questionnaire conducted by Azmi, et al. [16].

Table 1. The Results of the questionnaire for the interactive learning multimedia application needs in science-physics subjects

\begin{tabular}{|c|c|c|c|c|c|c|}
\hline Indicator & No & Statement & $\begin{array}{c}\text { Strongly } \\
\text { Agree }\end{array}$ & Agree & Disagree & $\begin{array}{l}\text { Strongly } \\
\text { Disagree }\end{array}$ \\
\hline \multirow{2}{*}{$\begin{array}{l}\text { Problems } \\
\text { teachers }\end{array}$} & 1 & I have difficulty teaching using textbooks only. & $26.5 \%$ & $55.1 \%$ & $16.3 \%$ & $2 \%$ \\
\hline & 3 & $\begin{array}{l}\text { I find it challenging to get multimedia learning } \\
\text { in physics on mobile applications. }\end{array}$ & $20.4 \%$ & $61.2 \%$ & $16.3 \%$ & $2 \%$ \\
\hline
\end{tabular}




\begin{tabular}{|c|c|c|c|c|c|c|}
\hline \multirow[t]{3}{*}{ Solution } & 1 & $\begin{array}{l}\text { Multimedia helps teachers in delivering } \\
\text { practical materials. }\end{array}$ & $18.4 \%$ & $44.9 \%$ & $24.5 \%$ & $12.2 \%$ \\
\hline & 2 & $\begin{array}{l}\text { Interactive learning multimedia is needed in } \\
\text { high school physics subjects. }\end{array}$ & $71.4 \%$ & $28.6 \%$ & $0 \%$ & $0 \%$ \\
\hline & 3 & $\begin{array}{l}\text { Interactive multimedia learning can support } \\
\text { high school physics learning activities. }\end{array}$ & $65.3 \%$ & $34.7 \%$ & $0 \%$ & $0 \%$ \\
\hline \multirow[t]{2}{*}{$\begin{array}{l}\text { Software } \\
\text { Requirements }\end{array}$} & 1 & $\begin{array}{l}\text { I prefer using a free interactive learning } \\
\text { multimedia application to a paid app. }\end{array}$ & $32.7 \%$ & $57.1 \%$ & $8.2 \%$ & $2 \%$ \\
\hline & 2 & $\begin{array}{l}\text { It takes an interactive learning multimedia } \\
\text { application in the android mobile version. }\end{array}$ & $49 \%$ & $51 \%$ & $0 \%$ & $0 \%$ \\
\hline
\end{tabular}

Based on the results of the questionnaire above, the problem faced by the teacher is that they feel difficult to teach using textbooks only and do not have enough time to make interactive learning multimedia. Most of them challenging to get multimedia learning in physics on mobile applications. Most of the teachers agree that learning multimedia is needed to help to deliver the material. In addition to learning activities, most teachers agree that interactive multimedia learning can increase student motivation. Most of them prefer using a free interactive learning multimedia application. All respondents agreed that it takes an interactive learning multimedia application in the android mobile version.

To find information on the condition of multimedia learning that has been used in schools and the expected interactive learning multimedia, other questions are asked of the respondent. The results are shown in Figure 1 to Figure 4 below.

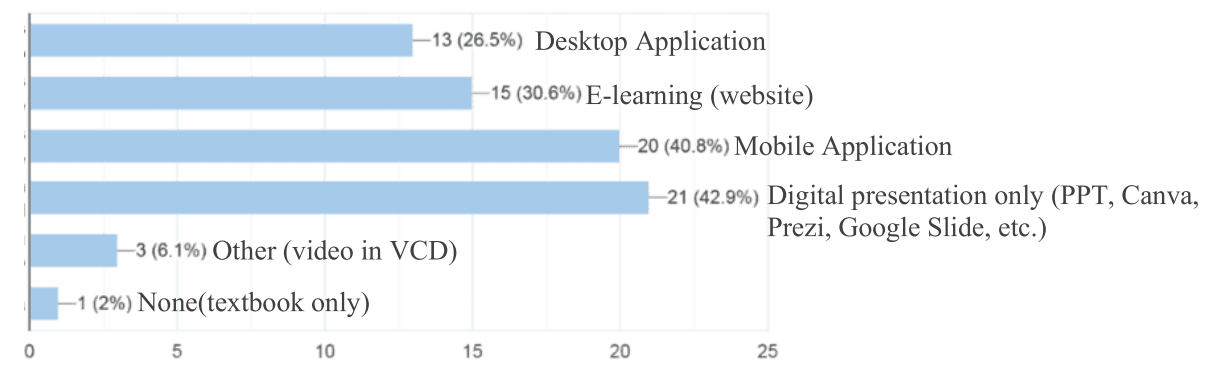

Figure 1. Learning multimedia that have been used in schools (the respondent can answer more than one choice)

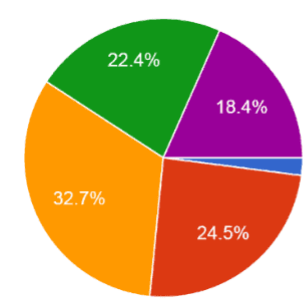

- Very Satitisfied (2\%)

Satisfied $(24.5 \%)$

Quite Satisfied $(32.7 \%)$

- Dissatisfied $(22.4 \%)$

- Very Dissatified (18.4\%)

Figure 2. Satisfaction in using multimedia that have been used.

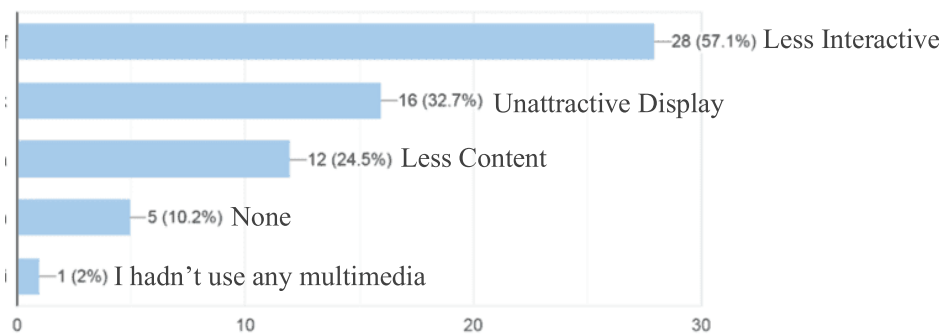

Figure 3. Features that are considered lacking in multimedia that have been used 


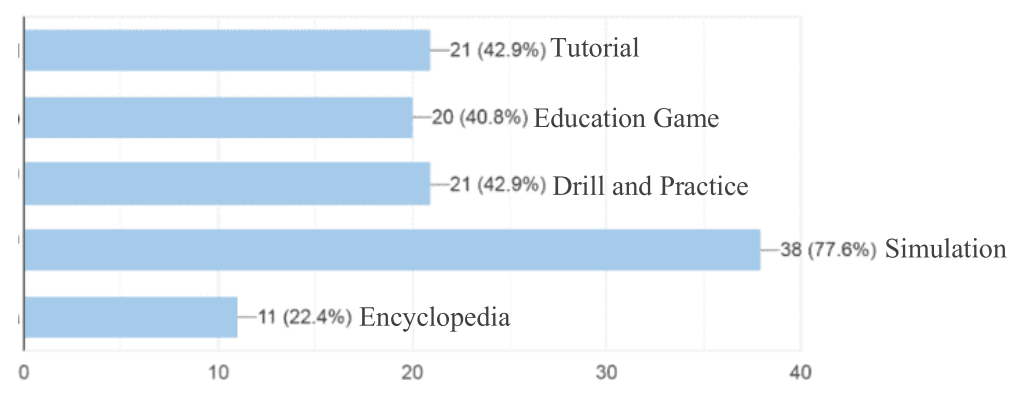

Figure 4. Features that expected in interactive multimedia learning

Based on the needs of mobile applications, the design of a mobile application that is being developed contains material content, animations, simulations, experiments, illustrations, and practice questions. The education game will be developed further.

\subsection{Design}

Instructional design, flowchart, screen design, and storyboarding were carried out.

\subsection{Production}

Product manufacturing starts from prototyping multimedia components (images, sound, video, animation) to packaging in the application form. Production is based on a design document.

\subsection{Evaluation}

In this case, an ongoing evaluation, alpha testing, and beta testing were carried out. The target of this step is a good or viable product. The alpha testing stage is carried out by experts followed by beta testing, by conducting field trials (schools) where the user, as the target user, becomes the evaluator. The trial was conducted to determine the usability of the application.

\subsubsection{Alpha testing stage}

At the alpha testing stage, first, the application is evaluated by material experts to evaluate whether the material displayed is following the applicable curriculum. Also, several other aspects, aspects of learning, aspects of material substance, and aspects of language. Several items in this questionnaire were adapted and modified from interactive learning multimedia quality criteria [4,16,17]. Evaluation of material experts using the following instruments in Table 2. Score one is Very Poor, two is Poor, three is Enough, four is Good, and five is Very Good.

Table 2. Results of Learning Multimedia Assessment Based on Learning Aspects and Material Substance Aspects by Material Expert

\begin{tabular}{|c|c|c|c|c|}
\hline Aspect & No & Statement & $\begin{array}{c}\text { Score } \\
(\text { Expert A) }\end{array}$ & $\begin{array}{c}\text { Score } \\
(\text { Expert B) }\end{array}$ \\
\hline \multirow[t]{9}{*}{ Learning Aspect } & 1 & $\begin{array}{l}\text { Clarity of material with learning objectives (reliability } \\
\text { and measurable). }\end{array}$ & 4 & 4 \\
\hline & 2 & $\begin{array}{l}\text { The relevance of the material to the curriculum / Standar } \\
\text { Kompetensi (SK) /Kompetensi Dasar (KD). }\end{array}$ & 5 & 5 \\
\hline & 3 & $\begin{array}{l}\text { The scope and depth of the material are following the } \\
\text { learning objective. }\end{array}$ & 5 & 4 \\
\hline & 4 & Interactivity. & 5 & 5 \\
\hline & 5 & Contextuality of content. & 5 & 5 \\
\hline & 6 & Ease of understanding. & 5 & 4 \\
\hline & 7 & A systematic, logical, and explisit systematic. & 5 & 5 \\
\hline & 8 & $\begin{array}{l}\text { Clarity of descriptions, discussions, examples, } \\
\text { simulations, and exercises. }\end{array}$ & 5 & 3 \\
\hline & 9 & Providing feedback on practice questions. & 4 & 3 \\
\hline \multirow{7}{*}{$\begin{array}{l}\text { Substance Aspect } \\
\text { of Material }\end{array}$} & 10 & Material truth in theory and concept. & 5 & 4 \\
\hline & 11 & $\begin{array}{l}\text { The accuracy of using terms according to the scientific } \\
\text { field. }\end{array}$ & 5 & 5 \\
\hline & 12 & Depth of material. & 5 & 4 \\
\hline & 13 & Accuracy of using symbols. & 5 & 4 \\
\hline & 14 & Accuracy of illustration. & 5 & 3 \\
\hline & 15 & The suitability of using animation with material. & 4 & 4 \\
\hline & 16 & The concatenation of the material presented. & 5 & 5 \\
\hline
\end{tabular}




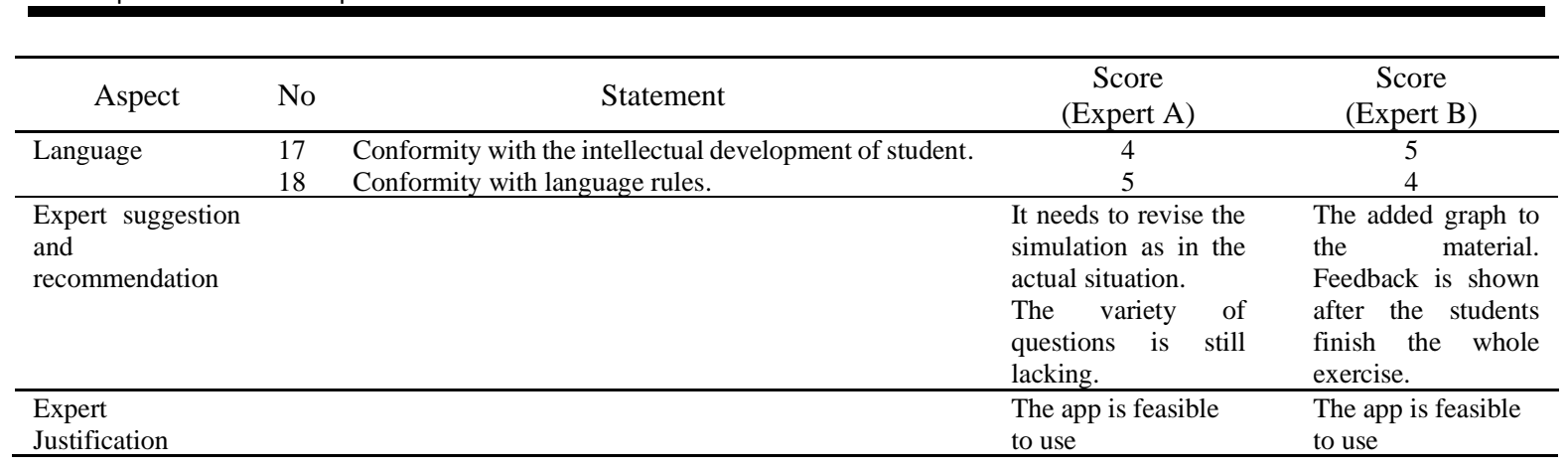

The evaluation results show that the application is feasible to use. However, several things need to be revised in the simulation section and adding variations to the practice questions. Second, the application is evaluated by an interactive multimedia learning expert. Several items in this questionnaire were adapted and modified from interactive learning multimedia quality criteria consist of general aspects, software aspects, and visual communication aspects [4,16,17]. Score one is Very Poor, two is Poor, three is Enough, four is Good, and five is Very Good. The results of the evaluation show that the application is feasible to use, as shown in Table 3.

Table 3. Results of learning multimedia assessment based general aspects, software aspects, and visual communication aspects by interactive learning multimedia expert.

\begin{tabular}{|c|c|c|c|}
\hline Aspect & No & Statement & $\begin{array}{c}\text { Score } \\
(\text { Expert C) }\end{array}$ \\
\hline \multirow[t]{3}{*}{ General Aspect } & 1 & $\begin{array}{l}\text { Creative and innovative (new, flexible, attractive, thoughtful, and } \\
\text { unique). }\end{array}$ & 5 \\
\hline & 2 & $\begin{array}{l}\text { Communicative (easy to understand and use suitable, correct, and } \\
\text { effective language). }\end{array}$ & 5 \\
\hline & 3 & $\begin{array}{l}\text { Superior (has advantages over other learning multimedia or conventional } \\
\text { methods). }\end{array}$ & 5 \\
\hline Software Engineering & 4 & Effective and efficient in the development and use of instructional media. & 5 \\
\hline \multirow[t]{7}{*}{ Aspects } & 5 & Reliability (reliability). & 5 \\
\hline & 6 & Maintainable (can be maintained or managed easily). & 4 \\
\hline & 7 & Usability (easy to use and simple in operation) & 5 \\
\hline & 8 & The accuracy of selecting the type of application/tool for development. & 5 \\
\hline & 9 & $\begin{array}{l}\text { Compatibility (learning media can be installed and run in various } \\
\text { existing hardware and software). }\end{array}$ & 5 \\
\hline & 10 & $\begin{array}{l}\text { The packaging of learning media programs is integrated and easy to } \\
\text { execute. }\end{array}$ & 5 \\
\hline & 11 & $\begin{array}{l}\text { Reusability (part or all of the multimedia learning can be reused to } \\
\text { develop other multimedia). }\end{array}$ & 5 \\
\hline \multirow{11}{*}{$\begin{array}{l}\text { Visual } \\
\text { Communication } \\
\text { Aspects }\end{array}$} & 12 & $\begin{array}{l}\text { Communicative: visual and audio elements support the teaching material } \\
\text { to be easily digested by a student. }\end{array}$ & 4 \\
\hline & 13 & $\begin{array}{l}\text { Creative: visualization is expected to be presented in a unique and not } \\
\text { cliché (often used), to attract attention. }\end{array}$ & 4 \\
\hline & 14 & $\begin{array}{l}\text { Simple: visualization is not complicated, so as not to reduce the clarity } \\
\text { of the content of the teaching material and easy to remember. }\end{array}$ & 5 \\
\hline & 15 & $\begin{array}{l}\text { Unity: use visual and audio language that is harmonious, intact, and in } \\
\text { tune, so that teaching materials are perceived as a whole } \\
\text { (comprehensive). }\end{array}$ & 5 \\
\hline & 16 & $\begin{array}{l}\text { Depiction of objects in the form of images (images) is good realistic, and } \\
\text { symbolic. }\end{array}$ & 5 \\
\hline & 17 & $\begin{array}{l}\text { Selection of appropriate colors, to support the fit between the creative } \\
\text { concept and the chosen topic. }\end{array}$ & 4 \\
\hline & 18 & $\begin{array}{l}\text { Typography (font and lettering), to visualize verbal language to support } \\
\text { the message content, both in terms of readability and psychological } \\
\text { functions. }\end{array}$ & 5 \\
\hline & 19 & $\begin{array}{l}\text { Layout (layout): laying and arrangement of elements visuals are well } \\
\text { controlled, to clarify the role and hierarchy of each of these elements. }\end{array}$ & 5 \\
\hline & 20 & $\begin{array}{l}\text { Moving visual elements (animation and, or movie), animation can be } \\
\text { used to simulate teaching materials and movies to illustrate actual } \\
\text { material. }\end{array}$ & 4 \\
\hline & 21 & Navigation that is familiar and consistent for practical use. & 5 \\
\hline & 22 & $\begin{array}{l}\text { Audio elements (dialogue, monologue, narration, music illustrations, and } \\
\text { sound/special effects) follow the character of the topic and are used to } \\
\text { enrich the imagination. }\end{array}$ & 4 \\
\hline $\begin{array}{l}\text { Expert suggestion and } \\
\text { recommendation }\end{array}$ & & $\begin{array}{l}\text { This application is good in terms of layout, image options, text } \\
\text { arrangement, and animation options. Furthermore, what needs to be }\end{array}$ & \\
\hline
\end{tabular}




\begin{tabular}{|c|c|c|c|}
\hline Aspect & No & Statement & $\begin{array}{c}\text { Score } \\
\text { (Expert C) }\end{array}$ \\
\hline & & $\begin{array}{l}\text { considered is that it allows communication or discussion of topics for } \\
\text { lesson content for users. }\end{array}$ & \\
\hline Expert Justification & & The app is feasible to use. & \\
\hline
\end{tabular}

\subsubsection{Beta Testing}

After the application is given input by the experts, the application is tested on target users using the SUS questionnaire. The questionnaire is then distributed and respondents were asked to answer all questions after they finished using the application as a whole. The application used Jawara Sains-Linear Motion version 1.0. After the data from respondents were collected, the data were processed. The score is then adjusted for the SUS assessment. The result then was analyzed.

The instrument used in this study is derived from SUS (System Usability Test). The SUS can be used by a broad group of usability practitioners to evaluate almost any type of user interface, a questionnaire consisting of ten statements as shown in Table 4 [10]. The answer choice consisted of strongly disagree to agree strongly. The odd statements are associated with positive wording statements while the even ones are negative. SUS provides a measure of a user's perception of the usability of a system. A system can be just about anything a human interacts with software application, mobile application, hardware, mobile device, or websites [18]. Initially, the SUS was written in English. Since the respondents in this study are the students and teachers from Indonesia, the instrument in this research used the Indonesian version of SUS, according to Shafrina and Santoso [19].

Table 4. System Usability Scale (SUS) original version

\begin{tabular}{cl}
\hline No & \\
\hline 1 & I think that I would like to use this product frequently \\
2 & I found the product unnecessarily complex. \\
3 & I thought the product was easy to use. \\
4 & I think that I would need the support of a technical person to be able to use this product. \\
5 & I found that the various functions in this product were well integrated. \\
6 & I thought there was too much inconsistency in this product. \\
7 & I would imagine that most people would learn to use this product very quickly. \\
8 & I found the product very cumbersome to use. \\
9 & I felt very confident using the product. \\
10 & I needed to learn many things before I could get going with this product.
\end{tabular}

After the instrument is completed, the questionnaire is then distributed. There were 56 students and teachers who participated in this study. This amount is suitable to measure usability. There is no certainty about the number of respondents used to obtain the results of usability evaluation [20]. However, the $16 \pm 4$ rule (meaning the number of users between 16-4 to 16+4) produces test results with a high level of validity. According to Roscoe[21], the sampling has met a viable sample size that the viable sample size in the study is between 30 to 500 .

After collecting data from respondents, the next step is to process the data. There are several rules in calculating the SUS score. The score for each answer to the questions in Table 4 starts from 1 to 5 . Each statement item in table 4 has a contribution score. For each odd-numbered question, the score for each question obtained from the scale position will be deducted by 1 . For each-even numbered, the contribution score is 5 subtract the scale position. Each item's contribution score will range from 0 to 4 . The total contribution score is then multiplied by 2.5 to get the overall value of the System Usability Scale [3]. SUS has a minimum score of 0 and a maximum score of 100 . Scores on the overall system usability scale are obtained from the average individual SUS score.

The resulting SUS scores are then interpreted into several categories, one of which is the category according to Sauro. The SUS score can be converted into aspects of Grade, Percentile, Adjectives, Acceptable, and NPS [18]. The following is a description of each aspect:

1. Acceptability Ranges, interpretation of SUS scores base of based on user acceptance. The rating scale used is Not Acceptable, Marginal, dan Acceptable.

2. Grade Scale, SUS scores are grouped into grades A, B, C, D, E, and F. Grades range from superior performance to failing performance, with $\mathrm{C}$ indicating average.

3. Adjective Rating, an adjective that translates the numerical score of SUS into an absolute rating of usability [10]. The rating scale for these adjectives includes Worst Imaginable, Awful, Poor, OK, Good, Excellent, Best Imaginable. 
4. Percentiles, raw SUS scores can be converted into percentile ranks. Using a scoring system ranging from 0 to 100 often leads to researchers interpreting SUS scores as percentages, which they are not. The normative data collected by Bangor, Kortum, and Miller [22] provided the basis for positioning SUS scores as percentiles. Percentile calculations compare the raw score of the research results with the database of previous studies.

5. Promoters and Detractors, Sauro [23] correlated the SUS score with the Net Promoter Score (NPS). NPS is a survey regarding the level of user satisfaction and loyalty towards a product which is related to the percentage of users likely to recommend the product to others. While promoters are most likely to recommend the app to a friend, detractors are more likely to discourage rather than recommend [18].

\section{RESULTS AND DISCUSSION}

\subsection{Jawara Sains Application}

Jawara Sains App is a mobile-based interactive science learning media with virtual simulations of scientific phenomena and experiments. The Jawara Sains application can be downloaded at http://jawarasains.id. Figure 5 shows the jawarasains.id landing page. The landing page will later be used to accommodate various exciting content on the various subject matter. Applications are made by developers and from teachers after they are given the training to make mobile learning by developers as an effort to help distance learning. The idea is to meet students' independent learning needs easily and can be accessed from anywhere and anytime.

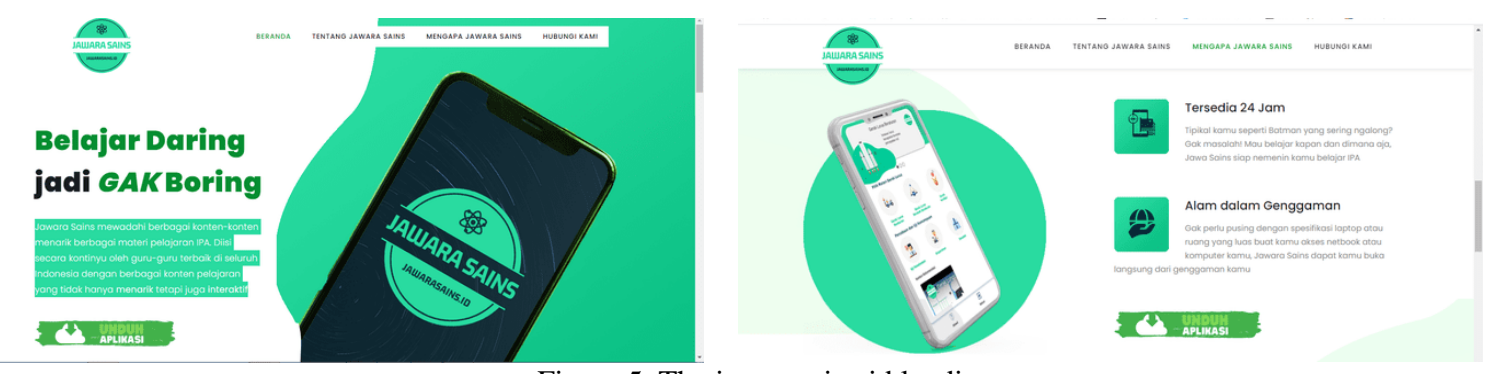

Figure 5. The jawarasains.id landing page

The application used in this research is Jawara Sains-Linear Motion version 1.0. This application offers several features consisting of videos of science learning materials, animations, formulas, explanatory text, work processes that can be observed by students. Figure 6 shows the main menu and some material content.
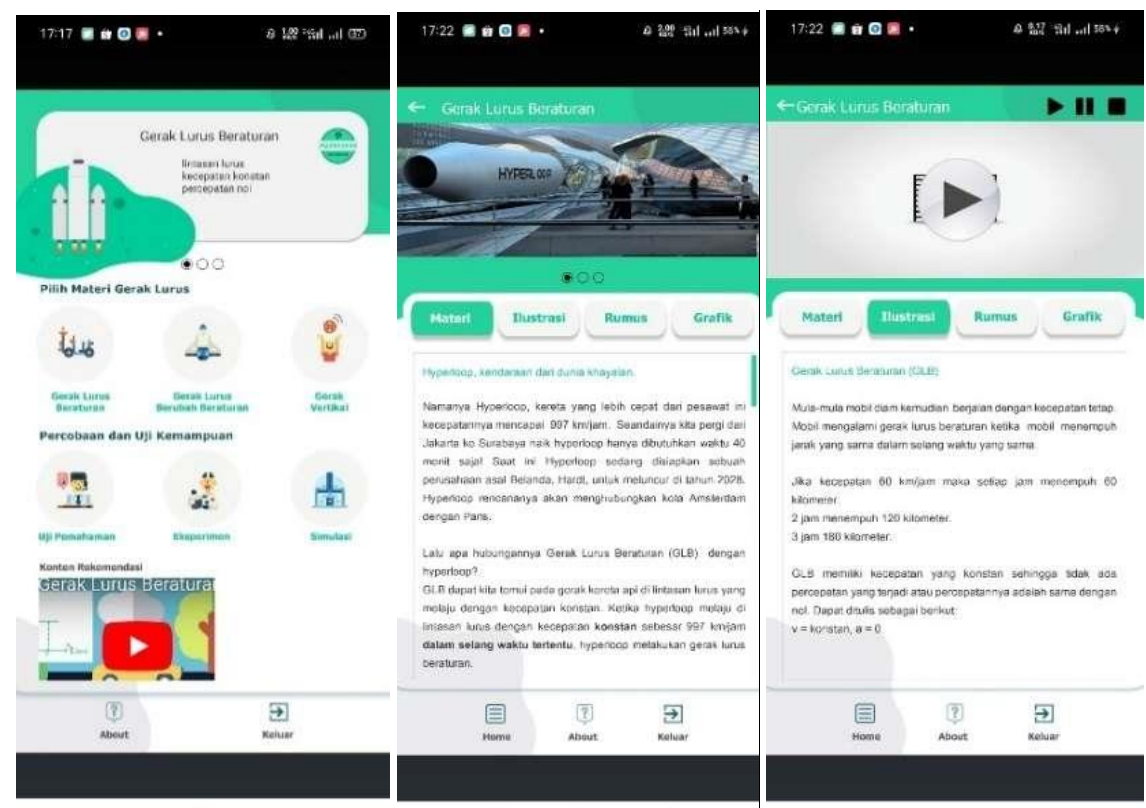

Figure 6. The main menu and material features display of Jawara Sains App 
The quiz feature helps students in self-evaluating and review student's answers against the correct answers. Students learn the smart way by doing experiments on their phones and explore ideas through interactive simulations. The Simulation feature is an interactive simulation for exploring science concepts. This feature is expected to engage students through an intuitive that promotes exploration and discovery. Same as the simulation feature, the experiment feature lets student's imagination flow and learn the wonders of science with easy experiments. Figure 7 shows the quiz, simulation, and experiment virtual features display of the Jawara Sains App.
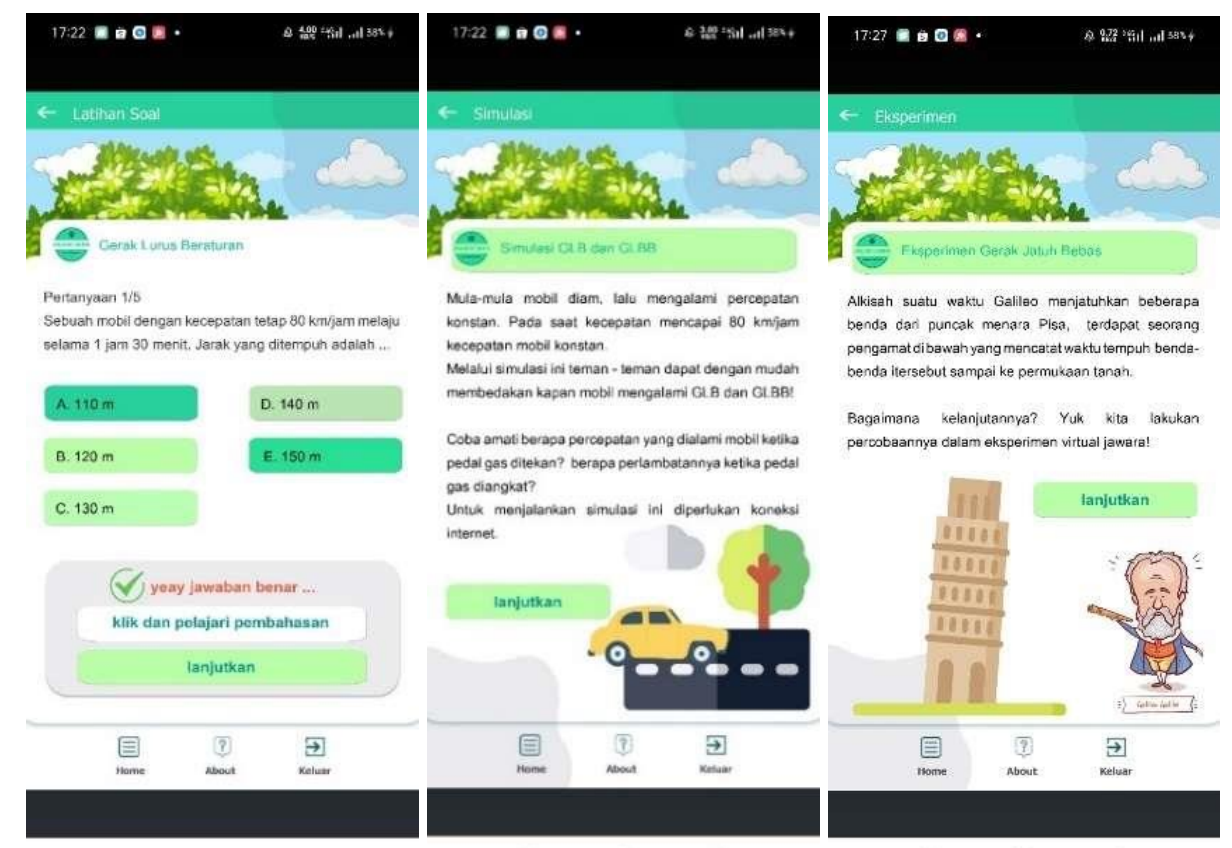

Figure 7. The quiz, simulation, and experiment virtual features display of Jawara Sains App

\subsection{The results of the SUS score assessment}

After the questionnaire was distributed, the responses obtained were 56 respondents. Respondents consisted of teachers and students. Respondents are users at schools that collaborate with Jawara Sains. The population is 120 respondents. Samples are more feasible if research is intended to explain the characteristics of each element of a population. Minimum returned of samples size were calculated by Slovin formula [24]:

$$
n=\frac{N}{1+N e^{2}}
$$

Where:

$\mathrm{n}=$ minimum returned of samples size

$\mathrm{N}=$ the population size

$\mathrm{e}=$ the degree of accuracy expressed as a proportion

The population size taken in this study is 120 with an error rate of $10 \%$, minimum returned of samples size used is as follows:

$$
\begin{aligned}
& n=\frac{120}{1+120(10 \%)^{2}} \\
& n=\frac{120}{1+120(0.01)} \\
& n=\frac{120}{1+1.2} \\
& n=\frac{120}{2.2} \\
& n=54.54
\end{aligned}
$$


These results indicate that the required sample must be more than 55 respondents. The questionnaire are then calculated using a predetermined formula to obtain a SUS score. The formula for calculating the SUS score for each respondent can be formulated as follows:

SUS Score for each respondent $=((R 1-1)+(5-R 2)+(R 3-1)+(5-R 4)+(R 5-1)+(5-R 6)+(R 7-1)$ $+(5-R 8)+(R 9-1)+(5-R 10)) * 2.5)$

$\mathrm{Rn}$ is the response to question $\mathrm{n}$ (for example $\mathrm{R} 1$ is the response to question 1). The results of the SUS score assessment are shown in Table 5. The SUS score of Jawara Sains application is 75.45.

Table 5. SUS calculation result data

\begin{tabular}{|c|c|c|c|c|c|c|c|c|c|c|c|}
\hline \multirow{2}{*}{ Respondent } & \multicolumn{10}{|c|}{ Item of Questions } & \multirow{2}{*}{$\begin{array}{l}\text { SUS } \\
\text { Score }\end{array}$} \\
\hline & R1-1 & $5-\mathrm{R} 2$ & R3-1 & $5-\mathrm{R} 4$ & R5-1 & 5-R6 & R7-1 & $5-\mathrm{R} 8$ & R9-1 & 5-R10 & \\
\hline 1 & 2 & 4 & 4 & 4 & 3 & 4 & 3 & 4 & 4 & 4 & 90 \\
\hline 2 & 2 & 2 & 2 & 1 & 2 & 1 & 2 & 2 & 3 & 1 & 45 \\
\hline 3 & 3 & 3 & 2 & 1 & 2 & 2 & 3 & 1 & 2 & 0 & 47.5 \\
\hline 4 & 3 & 3 & 3 & 3 & 3 & 4 & 4 & 4 & 3 & 4 & 85 \\
\hline 5 & 3 & 4 & 4 & 3 & 3 & 3 & 3 & 3 & 3 & 1 & 75 \\
\hline 6 & 4 & 3 & 4 & 1 & 3 & 2 & 3 & 3 & 3 & 2 & 70 \\
\hline 7 & 2 & 3 & 3 & 1 & 3 & 2 & 3 & 4 & 3 & 2 & 65 \\
\hline 8 & 2 & 2 & 3 & 1 & 2 & 3 & 4 & 3 & 3 & 1 & 60 \\
\hline 9 & 2 & 2 & 2 & 1 & 2 & 2 & 2 & 3 & 2 & 2 & 50 \\
\hline 10 & 3 & 3 & 3 & 2 & 4 & 2 & 3 & 3 & 4 & 1 & 70 \\
\hline 11 & 2 & 3 & 3 & 3 & 2 & 3 & 2 & 3 & 2 & 3 & 65 \\
\hline 12 & 2 & 3 & 3 & 1 & 2 & 3 & 2 & 3 & 2 & 0 & 52.5 \\
\hline 13 & 1 & 4 & 4 & 2 & 4 & 4 & 4 & 3 & 3 & 1 & 75 \\
\hline 14 & 4 & 3 & 3 & 3 & 3 & 4 & 4 & 3 & 4 & 2 & 82.5 \\
\hline 15 & 2 & 2 & 2 & 2 & 2 & 2 & 2 & 2 & 2 & 2 & 50 \\
\hline 16 & 3 & 2 & 2 & 0 & 4 & 2 & 4 & 3 & 4 & 0 & 60 \\
\hline 17 & 2 & 2 & 1 & 0 & 2 & 2 & 1 & 2 & 1 & 0 & 32.5 \\
\hline 18 & 4 & 4 & 4 & 1 & 3 & 4 & 4 & 4 & 4 & 3 & 87.5 \\
\hline 19 & 4 & 4 & 4 & 1 & 3 & 3 & 3 & 3 & 3 & 4 & 80 \\
\hline 20 & 3 & 4 & 4 & 1 & 3 & 3 & 4 & 4 & 3 & 3 & 80 \\
\hline 21 & 3 & 1 & 4 & 0 & 2 & 1 & 3 & 2 & 3 & 1 & 50 \\
\hline 22 & 4 & 4 & 4 & 0 & 3 & 3 & 4 & 4 & 3 & 3 & 80 \\
\hline 23 & 3 & 3 & 3 & 4 & 3 & 3 & 4 & 4 & 3 & 4 & 85 \\
\hline 24 & 4 & 4 & 4 & 3 & 3 & 3 & 3 & 3 & 3 & 3 & 82.5 \\
\hline 25 & 4 & 3 & 3 & 1 & 3 & 3 & 3 & 3 & 3 & 3 & 72.5 \\
\hline 26 & 4 & 3 & 3 & 4 & 4 & 4 & 4 & 3 & 3 & 4 & 90 \\
\hline 27 & 4 & 4 & 4 & 4 & 3 & 3 & 4 & 3 & 3 & 4 & 90 \\
\hline 28 & 4 & 4 & 4 & 4 & 3 & 3 & 4 & 4 & 4 & 4 & 95 \\
\hline 29 & 3 & 3 & 3 & 3 & 3 & 3 & 3 & 3 & 3 & 3 & 75 \\
\hline 30 & 4 & 4 & 4 & 3 & 3 & 3 & 3 & 3 & 3 & 4 & 85 \\
\hline 31 & 4 & 3 & 3 & 4 & 3 & 3 & 4 & 3 & 3 & 4 & 85 \\
\hline 32 & 3 & 4 & 4 & 4 & 3 & 3 & 3 & 4 & 4 & 3 & 87.5 \\
\hline 33 & 3 & 3 & 3 & 4 & 4 & 4 & 3 & 4 & 4 & 4 & 90 \\
\hline 34 & 3 & 3 & 3 & 3 & 3 & 3 & 3 & 3 & 3 & 3 & 75 \\
\hline 35 & 3 & 3 & 3 & 3 & 3 & 3 & 3 & 3 & 3 & 4 & 77.5 \\
\hline 36 & 4 & 3 & 3 & 4 & 4 & 4 & 3 & 3 & 3 & 3 & 85 \\
\hline 37 & 3 & 3 & 3 & 3 & 3 & 3 & 3 & 3 & 3 & 3 & 75 \\
\hline 38 & 4 & 4 & 4 & 4 & 3 & 3 & 4 & 3 & 4 & 4 & 92.5 \\
\hline 39 & 3 & 3 & 3 & 3 & 3 & 3 & 3 & 3 & 3 & 3 & 75 \\
\hline 40 & 4 & 4 & 4 & 3 & 4 & 4 & 4 & 4 & 4 & 4 & 97.5 \\
\hline 41 & 3 & 3 & 3 & 3 & 3 & 3 & 4 & 4 & 4 & 4 & 85 \\
\hline 42 & 3 & 3 & 3 & 3 & 3 & 3 & 3 & 3 & 3 & 3 & 75 \\
\hline 43 & 3 & 3 & 3 & 3 & 3 & 3 & 3 & 3 & 3 & 3 & 75 \\
\hline 44 & 2 & 0 & 4 & 0 & 4 & 0 & 3 & 0 & 2 & 0 & 37.5 \\
\hline 45 & 4 & 3 & 3 & 4 & 4 & 3 & 4 & 3 & 3 & 4 & 87.5 \\
\hline 46 & 3 & 3 & 3 & 4 & 3 & 3 & 4 & 3 & 3 & 4 & 82.5 \\
\hline 47 & 4 & 3 & 3 & 3 & 3 & 3 & 4 & 3 & 3 & 4 & 82.5 \\
\hline 48 & 4 & 3 & 3 & 4 & 3 & 3 & 4 & 3 & 3 & 4 & 85 \\
\hline 49 & 3 & 3 & 3 & 3 & 3 & 3 & 3 & 3 & 3 & 3 & 75 \\
\hline 50 & 3 & 3 & 3 & 3 & 3 & 3 & 3 & 3 & 3 & 4 & 77.5 \\
\hline 51 & 4 & 4 & 4 & 4 & 3 & 3 & 4 & 3 & 4 & 4 & 92.5 \\
\hline 52 & 4 & 3 & 3 & 4 & 3 & 3 & 4 & 4 & 4 & 3 & 87.5 \\
\hline 53 & 4 & 3 & 3 & 4 & 3 & 3 & 3 & 3 & 4 & 4 & 85 \\
\hline 54 & 3 & 3 & 3 & 3 & 3 & 3 & 3 & 3 & 3 & 3 & 75 \\
\hline 55 & 4 & 3 & 3 & 3 & 3 & 3 & 3 & 3 & 3 & 4 & 80 \\
\hline 56 & 3 & 3 & 3 & 3 & 3 & 3 & 3 & 3 & 3 & 3 & 75 \\
\hline \multicolumn{11}{|c|}{ SUM } & 4225 \\
\hline \multicolumn{11}{|c|}{ SUS Score } & 75.45 \\
\hline
\end{tabular}




\subsection{Instrument Validity Test Result}

The validity test was carried out using SPSS to the questionnaire answers from 56 respondents. The results of the validity test are shown in Table 6. The validity test uses Pearson (2 tails) with a significance level of 5\%. The results are considered valid if $r_{\text {count }}>r_{\text {table }}$ [21], with $r_{\text {table }}$ of 0.263 . Table 6 shows that the $r$ on the 10 questionnaire items is greater than the $\mathrm{r}_{\text {table }}$, so that the 10 questionnaire items are valid. Where $\mathrm{Q} i=$ question $\mathrm{i}$ (for example, Q1 is question item 1).

\begin{tabular}{cccc}
\multicolumn{4}{c}{ Table 6. Summary of validity test results } \\
\hline Q & $\mathrm{r}_{\text {count }}$ & $\mathrm{r}_{\text {table }}$ & Result \\
\hline Q1 & 0,657 & 0,263 & valid \\
Q2 & 0,748 & 0,263 & valid \\
Q3 & 0,547 & 0,263 & valid \\
Q4 & 0,759 & 0,263 & valid \\
Q5 & 0,514 & 0,263 & valid \\
Q6 & 0,767 & 0,263 & valid \\
Q7 & 0,679 & 0,263 & valid \\
Q8 & 0,713 & 0,263 & valid \\
Q9 & 0,718 & 0,263 & valid \\
Q10 & 0,839 & 0,263 & valid \\
\hline
\end{tabular}

\subsection{Instrument Reliability Test Result}

Reliability test using Cronbach's Alpha will be considered reliable if the value is greater than 0.7 . The results using SPSS show that the Cronbach's Alpha value for the ten questionnaire items is 0.873 , greater than 0.7 so that this questionnaire is considered reliable. The reliability test results from SPSS are shown in Table 7.

\begin{tabular}{ccc}
\multicolumn{3}{c}{ Table 7. Cronbach Alpha reliability test results } \\
\hline Alfa Cronbach & $\begin{array}{c}\text { Number of } \\
\text { items }\end{array}$ & $\begin{array}{c}\text { Reliability } \\
\text { Result }\end{array}$ \\
\hline 0.873 & 10 & Reliable \\
\hline
\end{tabular}

\subsection{SUS Score Analysis}

SUS is a global assessment of the subjective aspects of reusability (effectiveness, efficiency, and satisfaction) perceived by users. The SUS score can indicate the level of user acceptance. The SUS score must be more than 71.1 [18] to be considered acceptable. By following the scoring in Table 5, a SUS score of the Jawara Sains App is 75.45, so this app is acceptable. A SUS score is usable but it could improve. A SUS score is not a percentage score but a total score out of 100 . To interpret a SUS scores more closely, it can be normalized to produce a percentile ranking, 75.45 include 70-79 percentile range. The score of 75.45 represents a percentile rank of around $73 \%$. This means that scorer 75.45 has higher perceived usability than $73 \%$ of all products test in the database. The resulting SUS scores are then interpreted into several categories, one of which is the category according to Sauro [18] which is shown in Table 8:

Table 8. Grade, Percentile, Adjectives, Acceptable, and NPS categories that describe the SUS Score.

\begin{tabular}{cccccc}
\hline Grade & SUS & Percentile Range & Adjective & Acceptable & NPS \\
\hline B & $74.1-77.1$ & $70-79$ & Good & Acceptable & Passive \\
\hline
\end{tabular}

Figure 8 shows the position of this app's SUS score. It can be seen that the Jawara Sains application's SUS score is included in the category of good and indicated as grade "B". The good category means the adjective rating of the usability of this application into an absolute rating is good. It means that there is a positive acceptance from the user, but the app has not received high satisfaction. Furthermore, the NPS score results are Passive as shown in Figure 8. It can cause the application to take a long time to be recognized by the target user. Making slight improvements to this app or user experience can convert Passives into the Promoter category, turning them into likely recommenders. Asking passives for their feedback about how this app can earn their recommendation then analyze their responses can be a solution. 


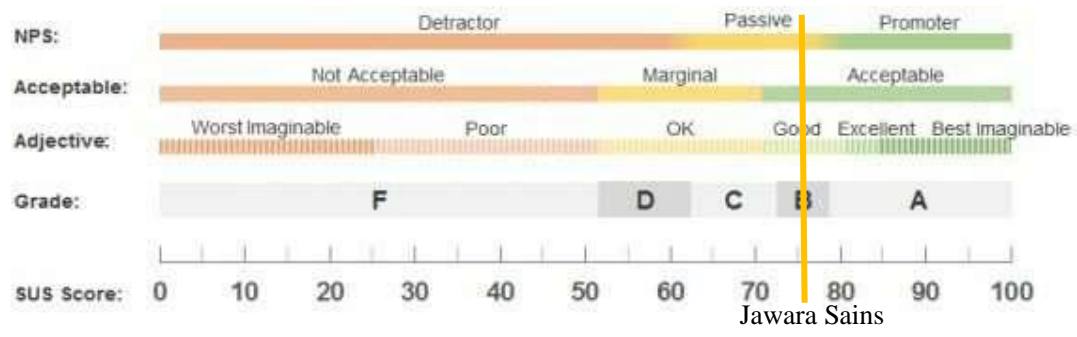

Figure 8. Grades, adjectives, acceptability, and NPS categories of Jawara Sains score based on The Sauro Category

\section{CONCLUSION}

Based on the result, the SUS Score of Jawara Sains App is 75.45, categorized as B grade. This indicates that the application is good and acceptable. Existing users are passives and do not recommend using the application to others. This can cause the target user cannot be met. The application needs to be evaluated during further development. This research should be continued to identify where improvements can be made for future version releases.

\section{ACKNOWLEDGEMENTS}

This research was supported by Kemenristek BRIN. We thank our colleagues from Universitas Muhammadiyah Bandung who provided insight and expertise that greatly assisted the research. However, they may not agree with all of the interpretations/conclusions of this paper.

\section{REFERENCES}

[1] S. Mariko and A. Andri, "Perancangan Software Aplikasi Berbasis Android untuk Menghitung Variabel Fisika Listrik dan Magnet," Jupiter (Jurnal Pendidik. Tek. Elektro), vol. 3, no. 1, p. 17, 2018, doi: 10.25273/jupiter.v3i1.2405.

[2] D. Ratnasari, D. Oktaviyanti, S. S. Sukmawati, and E. Setiyawati, "Pengembangan Mobile Learning Berbasis Program APPYPIE untuk Pembelajaran Fisika," J. Penelit. Pendidik. Fis., vol. 5, no. 2, p. 158, 2020, DOI: 10.36709/jipfi.v5i2.13149.

[3] J. Brooke, "SUS : A Retrospective," J. Usability Stud., vol. 8, no. 2, pp. 29-40, 2013, [Online]. Available: https://uxpajournal.org/sus-a-retrospective/.

[4] H. D. Surjono, Multimedia Pembelajaran Interaktif. Yogyakarta: UNY Press, 2017.

[5] Siswanto, S. Gumilar, Yusiran, and E. Trisnowati, "Scientific Approach-Integrated Virtual Simulation: a Physics Learning Design To Enhance Student'S Science Process Skills (Sps)," Unnes Sci. Educ. J., vol. 7, no. 1, pp. 712, 2018, DOI: 10.15294/usej.v7i1.21359.

[6] R. Vebrianto and K. Osman, "The effect of multiple media instruction in improving students' science process skill and achievement," Procedia - Soc. Behav. Sci., vol. 15, pp. 346-350, 2011, DOI: 10.1016/j.sbspro.2011.03.099.

[7] A. Khamparia and B. Pandey, "Impact of interactive multimedia in E-learning technologies: Role of multimedia in E-learning," Enhancing Acad. Res. With Knowl. Manag. Princ., no. March, pp. 199-227, 2017, DOI: 10.4018/978-1-5225-2489-2.ch007.

[8] "ISO 9241-11:2018(en), Ergonomics of human-system interaction - Part 11: Usability: Definitions and concepts." https://www.iso.org/obp/ui/\#iso:std:iso:9241:-11:ed-2:v1:en (accessed Oct. 05, 2020).

[9] J. Rubin and D. Chisnell, Handbook of Usability Testing How to Plan, Design, and Conduct Effective Tests. Indiana: Wiley Publishing, 2008.

[10] A. Bangor, T. Staff, P. Kortum, J. Miller, and T. Staff, "Determining what individual SUS scores mean: adding an adjective rating scale," J. usability Stud., vol. 4, no. 3, pp. 114-123, 2009.

[11] J. Kirakowski, "Background notes on the SUMI questionnaire." http://sumi.uxp.ie/about/sumipapp.html (accessed Nov. 08, 2020).

[12] K. L. Chin, J.P., Diehl, V.A., Norman, "Questionnaire for User Interface Satisfaction," Dev. an Instrum. Meas. User Satisf. Human-Computer Interface, no. 1988, p. ACM CHI'88 Proceedings, 213-218, 1988, [Online]. Available: http://garyperlman.com/quest/quest.cgi?form=QUIS.

[13] J. Sauro, "MeasuringU: 10 Things to Know About the Post Study System Usability Questionnaire," 2019. https://measuringu.com/pssuq/ (accessed Oct. 08, 2020).

[14] T. S. Tullis and J. N. Stetson, "A Comparison of Questionnaires for Assessing Website Usability," Usability Prof. Assoc. Conf., pp. 1-12, 2004, [Online]. Available: http://home.comcast.net/ tomtullis/publications/UPA2004TullisStetson.pdf.

[15] J. Sauro, "MeasuringU: Measuring Usability with the System Usability Scale (SUS)," 2011. https://measuringu.com/sus/ (accessed Oct. 05, 2020).

[16] R. Supriadi, "Media Pembelajaran Interaktif Perangkat Lunak Pengolah Angka Untuk Kelas XI SMA Negeri 2 Wates," J. Chem. Inf. Model., vol. 53, no. 9, pp. 1689-1699, 2012. 
[17] R. S. Wahono, “Aspek dan Kriteria Penilaian Media Pembelajaran." https://romisatriawahono.net/2006/06/21/aspek-dan-kriteria-penilaian-media-pembelajaran/ (accessed Oct. 8, 2020).

[18] J. Sauro, "MeasuringU: 5 Ways to Interpret a SUS Score," 2018. https://measuringu.com/interpret-sus-score/ (accessed Nov. 07, 2020).

[19] Z. Sharfina and H. B. Santoso, "An Indonesian adaptation of the System Usability Scale (SUS)," in 2016 International Conference on Advanced Computer Science and Information Systems (ICACSIS), 2016, pp. 145148, DOI: 10.1109/ICACSIS.2016.7872776.

[20] R. Alroobaea and P. J. Mayhew, "How many participants are really enough for usability studies?," Proc. 2014 Sci. Inf. Conf. SAI 2014, no. October 2017, pp. 48-56, 2014, doi: 10.1109/SAI.2014.6918171.

[21] Sugiyono, Metode Penelitian Pendidikan Pendekatan Kuantitatif, Kualitatif, dan R\&D. Bandung: Alfabeta, 2014.

[22] A. Bangor, P. Kortum, and J. Miller, "An empirical evaluation of the System Usability Scale," Int. J. Hum. Comput. Interact., vol. 24, no. 6, pp. 574-594, 2008, DOI: 10.1080/10447310802205776.

[23] J. Sauro, "MeasuringU: Predicting Net Promoter Scores from System Usability Scale Scores," 2012. https://measuringu.com/nps-sus/ (accessed Nov. 06, 2020).

[24] A. M. Adam, "Sample Size Determination in Survey Research," J. Sci. Res. Reports, vol. 26, no. 5, pp. 90-97, 2020, DOI: $10.9734 /$ jsrr/2020/v26i530263. 